\title{
The Effects of Sub-lethal Concentrations of Sodium Fluoride on the Number and Diameters of Ovarian Follicles
}

\author{
Hadeel, B. AL-Sabaawy ${ }^{1}$ and Bushra, I. AL-Kaisie ${ }^{2}$ \\ ${ }^{1}$ Department of pathology and poultry disease, Collage of Veterinary Medicine, University of Mosul, Iraq. \\ ${ }^{2}$ Department of pathology and poultry disease, Collage of Veterinary Medicine, University of Baghdad, Iraq. \\ *Corresponding Author, Hadeel, B. AL-Sabaawy, E-Mail: hadeelbasim2006@ gmail.com
}

\begin{abstract}
Fluoride was the first compound utilized in the fluoridation of drinking water, and still used today to prevent dental caries. Sodium fluoride exerts it toxic effects on different organs. Ovarian follicle considered as the fundamental unit of ovary. The current work aimed to study the toxic effects of sodium fluoride $(\mathrm{NaF})$ on the number and diameters of ovarian follicles. Twenty seven adults, non-pregnant female albino rats were used in this study. Rats were randomly divided into three equal groups. The $1^{\text {st }}$ group was untreated group, $2^{\text {nd }}$ group was treated with $150 \mathrm{ppm}$ of sodium fluoride by gavage daily for 90 days and the third group was treated with sodium fluoride (300ppm) by gavage daily for 90 days. The sodium fluoride had adverse effects on the number and diameters of ovarian follicle in both treated groups in contrast to the control group. Also in addition, inhibition of the maturation of ovarian follicles. These results suggest that sodium fluoride damage the structures of ovary, and has adverse effects on the coefficient of the female reproductive system.
\end{abstract}

Keywords: Albino rats, Dental caries, Diameters, Fluoridation, Ovarian follicle, Sodium fluoride.

J. Appl. Vet. Sci., 6(3 ): $20-24$.

\section{Original Article: \\ DOI:https://dx.doi.org/10.21608/javs.2 $\underline{021.74681 .1077}$}

Received :30 April, 2021.

Accepted:07 June, 2021.

Published in July, 2021.

This is an open access article under the term of the Creative Commons Attribution 4.0 (CC BY) International License. To view a copy of this license, visit:

http://creativecommons.org/licenses/by/4.0/

\section{INTRODUCTION}

Excessive exposure to pollutant and toxic materials in the environment is a major cause of reproductive health problems. Metal toxicity like aluminum, mercury, fluoride and lead effects on the coefficient of organs and inducing damage even at low level ( $\mathbf{A L}$ Taee et al., 2020). Fluoride is a common pollutant found in nature ( Piyal and Alok, 2018 ). Chronic fluoride exposure causes osteon and dental abnormalities (Choubisa, 2013); neurological disorders; disturbances of gastrointestinal tract, and disorders of the reproductive system (Choubisa, 2012). The association between long-term fluoride exposure and impairment of fertility has piqued peoples interest ((Choubisa ,2012).

Clinical research and trials on experimental animals suggested that, sodium fluoride has adverse effects on the male reproductive system ( AL-Sabaawy and AL-Kaisie, 2020). Hormones play important role in the singling pathway of endocrine system (Abdel Dayem et al., 2020). Thyroid gland hormones stimulate the consumption of $\mathrm{O} 2$ cell in the body, that help in regulate the metabolism of carbohydrate and lipid which are necessary for the maturation of tissue like uterus endometrium and ovary ( Krassas $\boldsymbol{e t}$ al., 2010 and Bakeer et al., 2021). Thyroid function is necessary for normal health and reproduction (Abdelsamad et al., 2018) as hormones of the thyroid gland effects on the reproductive system at all levels. Thyroid hormone receptors are expressed by stromal cell and granulose cell of the ovary; thus, thyroid hormones play an important role in the ovarian physiology.

Administration of big with 100,250, and $400 \mathrm{mg} / \mathrm{kg}$ of $\mathrm{NaF}$ for 50 days showed marked decreased in T4, and increase in TSH; these related to decrease of iodine level in the thyroid gland due to fluoride toxicity (Zhan et al., 2006). Female reproductive system is inhibited by hypothyroidism and hyperthyroidism (Kang et al., 2013). Estrus cycle is characterized by morphological changes in the uterus and ovary (Arbind, 2015). Decreased estrus cycle and disturbances of ovulation was observed in mice according to the previously mentioned facts. Due to lack of data on the effects of sodium fluoride on the female reproductive system, the current study was 
conducted to evaluate the toxic effects of sub-lethal doses of sodium fluoride on the number and diameters of the ovarian follicles.

\section{MATERIIALS AND METHODS}

\section{Animals:}

Twenty seven adults, non-pregnant female albino rats were used in this study .The weight ranged from 200-250 grams. The age ranged from 90 to 100 days. The animals were held in cages and kept at room temperature in the animal house at College of Veterinary Medicine University of Mosul. The rations and water were continuously served freely distributed.

\section{Experiment design:}

Animals were divided into three equal group, the first group was untreated (control group) which received tap water for 90 days and standard rat pellet ; while the $2^{\text {nd }}$ group received $150 \mathrm{ppm}$ of sodium fluoride $(\mathrm{NaF})$ by gavage daily for 90 days and the $3^{\text {rd }}$ group received $300 \mathrm{ppm}$ of sodium fluoride by gavage, daily for 90 days. All animals were adapted for at least one week before the day of dosing. Following scarifying of the empirical animals at 90 days the ovaries were extracted and fixed in $10 \%$ formaldehyde. The normal histological procedures were used to dehydrate the samples and embedded in paraffin wax. Each section was cut into $4-5 \mathrm{~mm}$ thickness, stained with Hematoxylin and Eosin and finally examined under the light microscope (Survarn et al., 2018).

\section{Evaluation of the ovarian follicle:}

All micro morphometric measurements of ovary were done using the colour USB 2.0 digital image camera (Novel-H1C) provided with image processing software (Scope Image 9.0- China). The camera's software was calibrated to all objective lenses of Microscope (Olympus CX31) with a $0.01 \mathrm{~mm}$ stage micrometer (ESM-11/Japan). The ovary's micro morphometric parameters include: (1) number of primordial, primary, secondary, mature and atretic follicles per section $/ \mu \mathrm{m}$, and (2) diameter of follicles $/ \mu \mathrm{m}$.

\section{RESULTS}

\section{Effects of sub lethal concentration of sodium} fluoride on the number of ovarian follicle:

Sodium fluoride toxicity on ovarian follicle number was showed in table (1) and Plate (1). Results of the both treated groups showed a significant decrease at $(p \leq 0.05)$ in the number of primordial, primary, and mature follicle when compared with the control group; while the number of secondary follicle showed significant reduction in the $3^{\text {rd }}$ group in contrast to the $1^{\text {st }}$ and $2^{\text {nd }}$ groups. The number of atretic and luteal follicle showed a significant decrease at $(p \leq 0.05)$ in both treated groups but the luteal and atretic follicle was the highest in the $3^{\text {rd }}$ groups when compared with the $1^{\text {st }} \& 2^{\text {nd }}$ groups.

Table 1: Effects of different sub-lethal concentrations of sodium fluoride on the ovarian follicle in each groups (mean $\pm \mathrm{SE}$ ).

\begin{tabular}{|c|c|c|c|c|c|c|}
\hline $\begin{array}{l}\text { an } \\
\stackrel{0}{0} \\
\stackrel{0}{0}\end{array}$ & 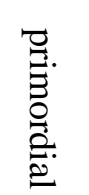 & 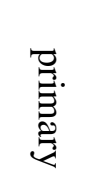 & 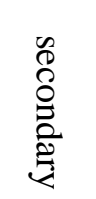 & $\underset{\text { है }}{\stackrel{\Xi}{艹}}$ & 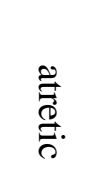 & 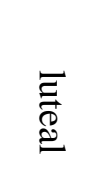 \\
\hline control & $\begin{array}{c}11 \\
\pm \\
0.7^{\mathrm{a}}\end{array}$ & $\begin{array}{c}11.2 \\
\pm \\
0.58^{\mathrm{a}}\end{array}$ & $\begin{array}{c}7.8 \\
\pm \\
0.37^{\mathrm{a}}\end{array}$ & $\begin{array}{c}3 \\
\pm \\
0.31^{\mathrm{a}}\end{array}$ & $\begin{array}{c}20.8 \\
\pm \\
0.73^{\mathrm{a}}\end{array}$ & $\begin{array}{c}18 \\
\pm \\
0.70\end{array}$ \\
\hline G150 & $\begin{array}{c}7 \\
\pm \\
0.3^{\mathrm{b}}\end{array}$ & $\begin{array}{c}3.4 \\
\pm \\
0.24^{\mathrm{b}}\end{array}$ & $\begin{array}{c}6.8 \\
\pm \\
0.34^{\mathrm{a}}\end{array}$ & $\begin{array}{c}4.2 \\
\pm \\
0.37^{\mathrm{b}}\end{array}$ & $\begin{array}{c}14.4 \\
\pm \\
0.81^{\mathrm{b}}\end{array}$ & $\begin{array}{c}9.6 \\
\pm \\
0.51^{b}\end{array}$ \\
\hline G 300 & $\begin{array}{c}6.6 \\
\pm \\
0.4^{\mathrm{b}}\end{array}$ & $\begin{array}{c}2.4 \\
\pm \\
0.25^{\mathrm{b}}\end{array}$ & $\begin{array}{c}3.4 \\
\pm \\
0.4^{\mathrm{c}}\end{array}$ & $\begin{array}{c}4.8 \\
\pm \\
0.37^{\mathrm{b}}\end{array}$ & $\begin{array}{c}4.4 \\
\pm \\
0.24^{\mathrm{c}}\end{array}$ & $\begin{array}{c}6.8 \\
\pm \\
0.37^{\circ}\end{array}$ \\
\hline
\end{tabular}

Values represent mean $\pm \mathrm{SE}$ ( $\mathrm{n}=9$ rats/group)

The same letters in columns means non-significant differences $(\mathrm{p} \leq 0.05)$ among ages

The different letters in columns means there is a significant difference $(p \leq 0.05)$ among ages

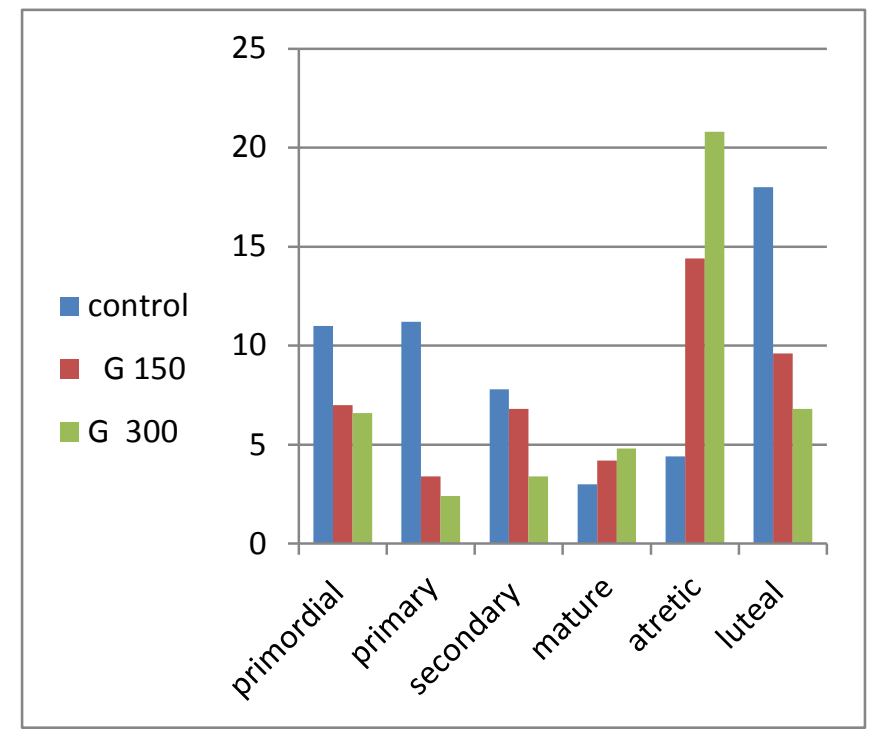

Plate 1: Number of ovarian follicles

\section{Effects of sub lethal concentration of sodium fluoride on the diameters of ovarian follicle:}

Table (2) and Plate (2) revealed a significant changes at $(p \leq 0.05)$ in the diameters of secondary and mature ovarian follicle in the both dose group in contrast to the control group while the corpus luteal diameters of the $3^{\text {rd }}$ group showed significant changes when compared with the $1^{\text {st }}$ and $2^{\text {nd }}$ group . 
Table 2: Effects of different sub lethal concentrations of sodium fluoride on the diameters of ovarian follicle (mean $\pm \mathrm{SE})$.

\begin{tabular}{|c|c|c|c|}
\hline group & secondary & mature & luteal \\
\hline \multirow{2}{*}{ control } & $182.38 \pm$ & $343.76 \pm$ & $633.31 \pm$ \\
& $16.02^{\mathrm{a}} \mu \mathrm{m}$ & $38.8^{\mathrm{a}} \mu \mathrm{m}$ & $106.5^{\mathrm{a}} \mu \mathrm{m}$ \\
\hline \multirow{2}{*}{ G 150 } & $220.02 \pm$ & $522.45 \pm$ & $631.76 \pm$ \\
& $23.3^{\mathrm{a}} \mu \mathrm{m}$ & $58.1^{\mathrm{b}} \mu \mathrm{m}$ & $65.8^{\mathrm{a}} \mu \mathrm{m}$ \\
\hline \multirow{2}{*}{ G 300 } & $227.85 \pm$ & $586.91 \pm$ & $511.51 \pm$ \\
& $21.3^{\mathrm{a}} \mu \mathrm{m}$ & $53.2^{\mathrm{b}} \mu \mathrm{m}$ & $126.5^{\mathrm{b}} \mu \mathrm{m}$ \\
\hline
\end{tabular}

The similar letters in columns means non-significant differences $(\mathrm{p}<0.05)$ among age's.

The different letters in columns means there is a significant difference $(\mathrm{p}<0.05)$ among age's.

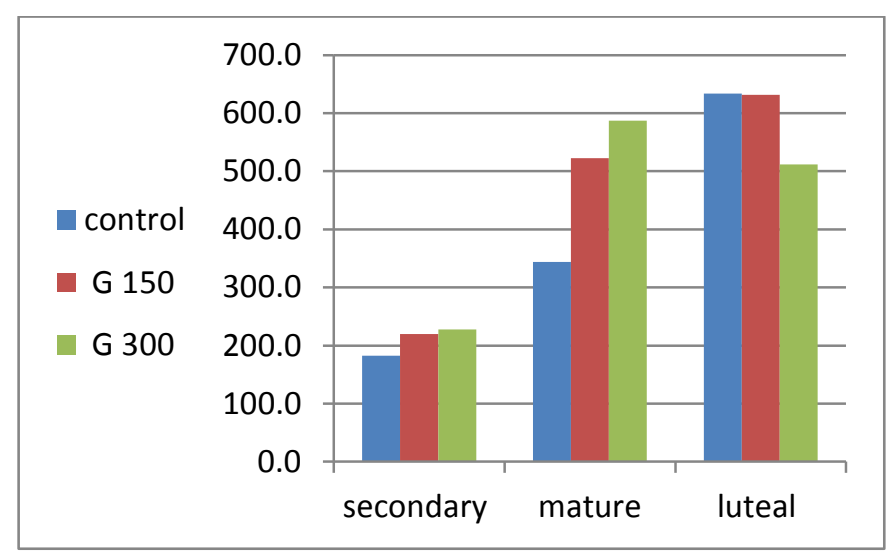

Plate 2: Diameters of ovarian follicles

\section{Microscopic examination of the number and diameters ovarian follicle: \\ Control groups}

The histological examination of the ovary control group showed normal composition of ovarian tissue, primordial follicles, corpus lutes, mature follicles and secondary follicles (Fig.1).

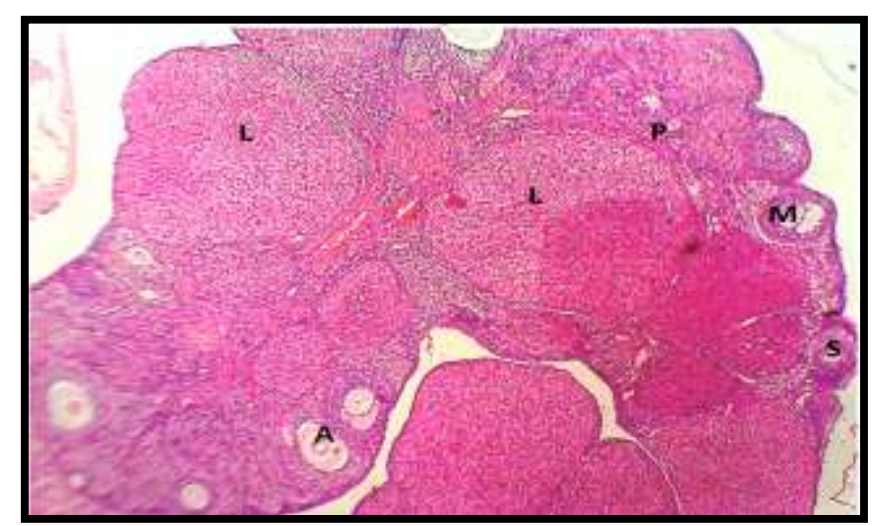

Fig.1: photomicrograph of ovary section of control group showed normal composition of ovarian tissue, primordial follicles $(\mathrm{P})$ (arrow ) ,corpus lutem (L), mature follicles (M), secondary follicles (S), stain H\&E, ( 40x).

\section{Ovary of the $2^{\text {nd }}(150 \mathrm{ppm})$ :}

The histological examination of the $2^{\text {nd }}$ ovary showed corpus lutes, mature follicles, secondary follicles (Fig. 2), atretic follicles, and primordial follicle(Figs.3,4) and mature follicle, primordial follicles (Fig.5).

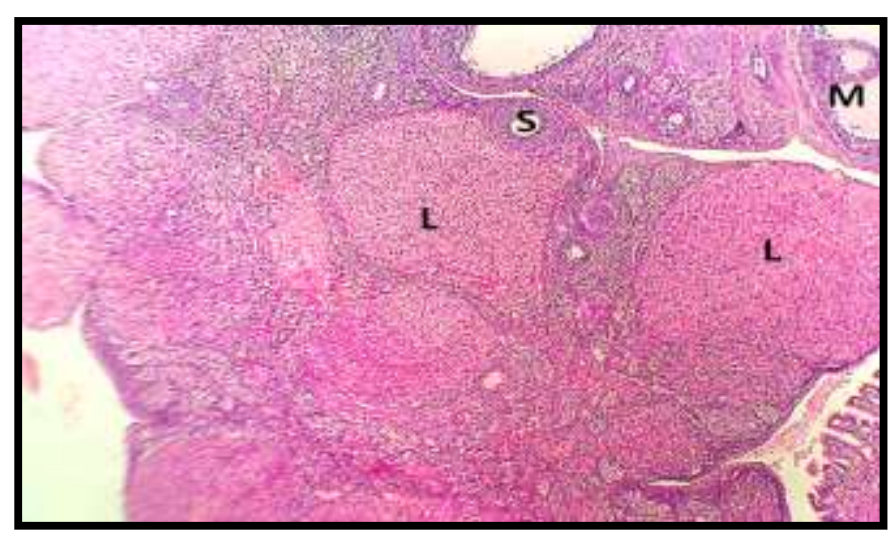

Fig. 2: Photomicrograph of ovary section of $2^{\text {nd }}$ group (150ppm)at 90 day showed corpus lutes (L), mature follicles $(M)$, secondary follicles (S), stain $H \& E,(40 x)$.

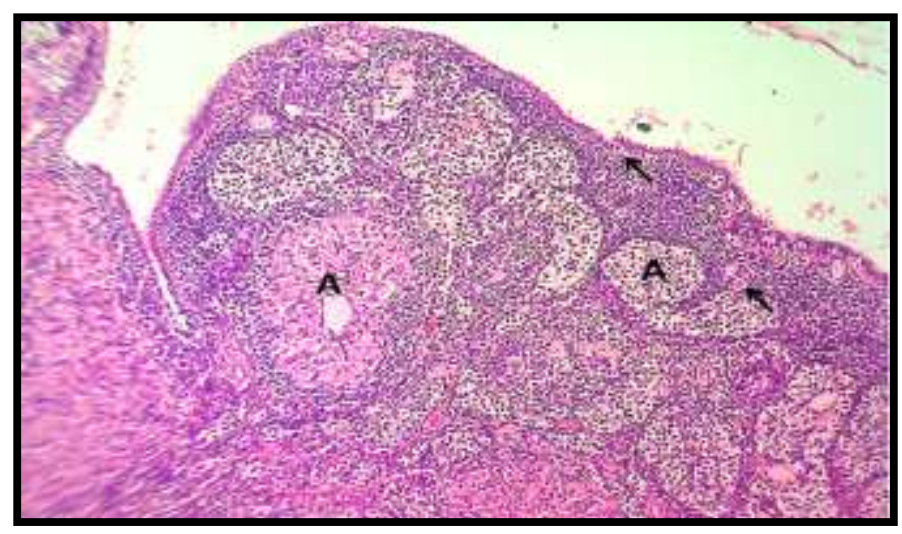

Fig. 3: Photomicrograph of ovary section of $2^{\text {nd }}$ group(150ppm)at 90 day showed atretic follicles(A) ,primordial follicle (arrow), stain H\&E,( 100x).

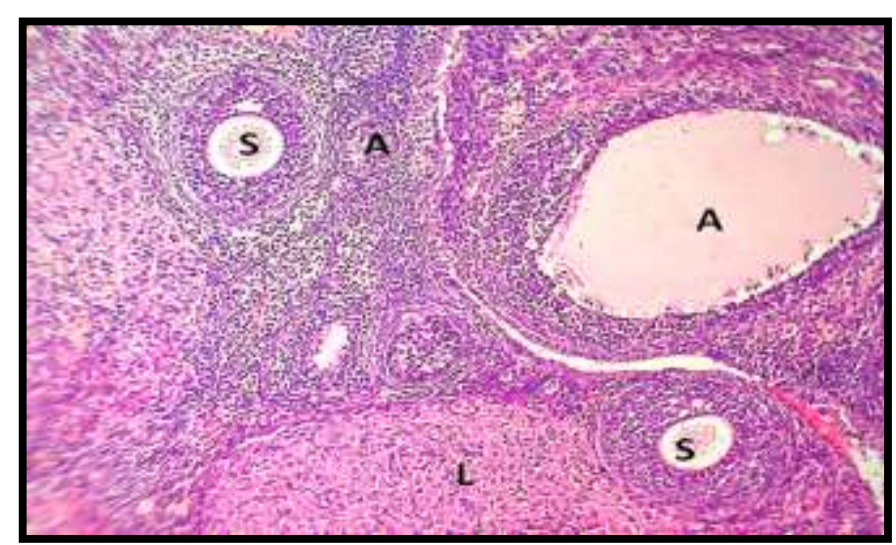

Fig. 4: Photomicrograph of ovary section of $2^{\text {nd }}$ group (150ppm)at 90 day showed Antral follicle (A) ,secondary follicle (S), corpus lutes(L)stain H\&E,( 100x). 


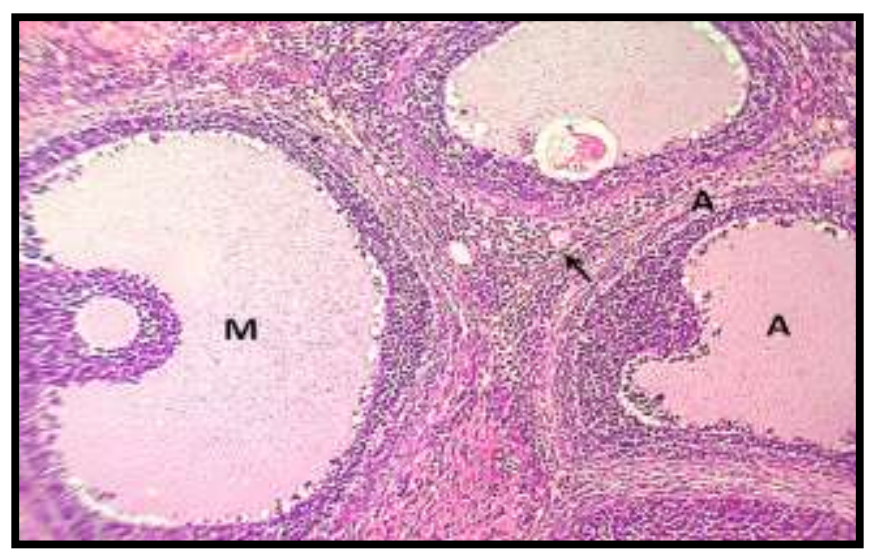

Fig. 5: Photomicrograph of ovary section of $2^{\text {nd }}$ group (150ppm)at 90 day showed Antral follicles atretic follicles(A) ,mature follicle $(\mathrm{M})$, primordial follicles (arrow )stain H\&E,( 100x).

\section{Ovary of the $3^{\text {rd }}$ group (300ppm):}

Histology of the $3^{\text {rd }}$ group ovary showed mature follicle, secondary follicles, atretic follicle and luteal follicle (Figs.6,7 and 8).

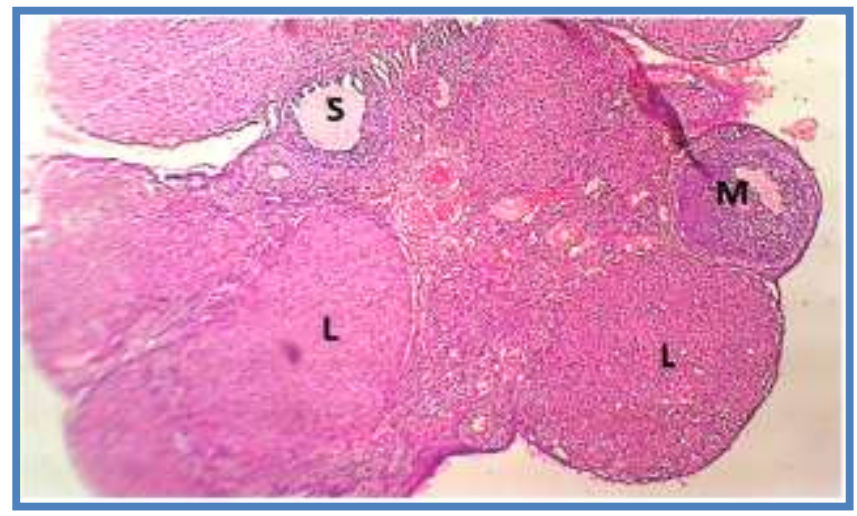

Fig. 6: photomicrograph of ovary section of $3^{\text {rd }}$ group (300ppm)at 90 day showed mature follicle (M), secondary follicles (S), corpus lutes(L) Stain H\&E, ( 40x).

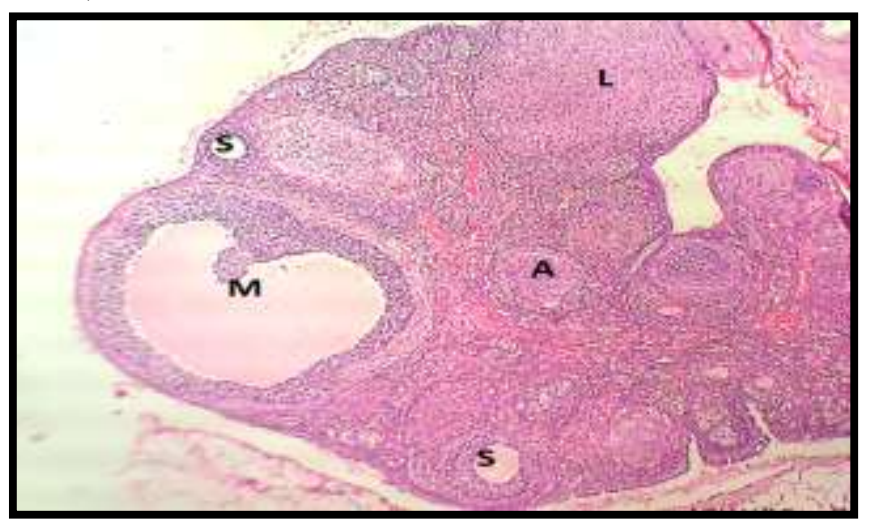

Fig. 7: Photomicrograph of ovary section of $3^{\text {rd }}$ group (300ppm)at 90 day showed mature follicle (M), secondary follicles (S), atretic follicle (A), lutel follicle (L),H\&E, (100x).

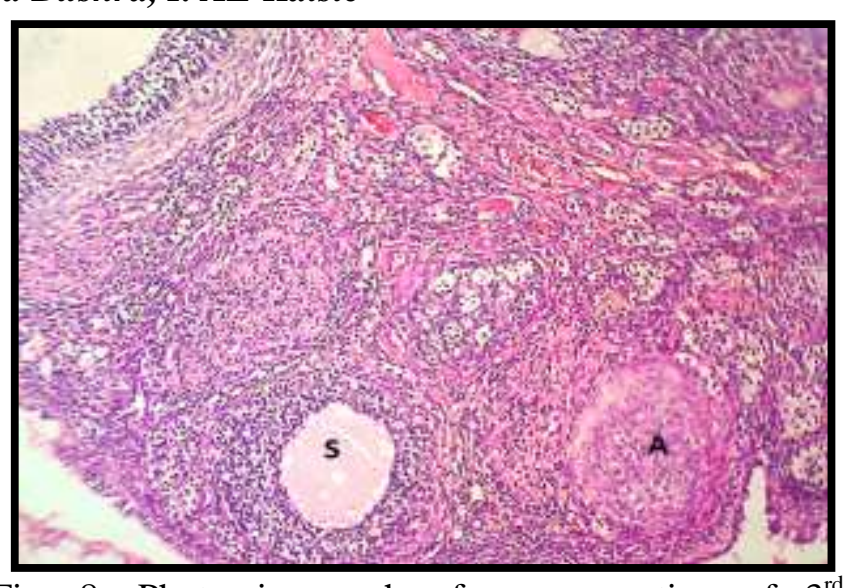

Fig. 8: Photomicrograph of ovary section of $3^{\text {rd }}$ group (300ppm)at 90 day showed secondary follicles (S), atretic follicle (A)stain H\&E, (100x).

\section{DISCUSSION}

The microscopic examination of the ovary in the both dosed adults albino rats showed decreased in the number and diameters of ovarian follicle most of them degenerated leading to increase number of the atretic follicle especially in the $3^{\text {rd }}$ group these result agree with Varsha et al., (2017) who attributed the decreased in the number and diameters of ovarian follicle in the both dosed group to decreased availability of the proteins necessary for cell growth, fluoride toxicity effects on the secretion of protein that synthesized in the endoplasmic reticulum and transported to plasma membrane and Golgi apertures, as well the biological consequences of fluoride toxicity including its effects on differentiation of germ cell during the production or development of an ovum, and cell division, or due to inhibition of hypothalamus by fluoride toxicity (Kinawy, 2019).

The toxicity with sodium fluoride damage the structures of thyroid gland, disturbed the secretion of hormone (Bouaziz et al., 2005) inducing hypothyroidism, thus in hypothyroid animals the ovarian follicle are not fully develop and these concerning to that thyroid hormone may have a direct impacts on the growth and development of ovarian follicles (Armada et al ., 2001). Thyroid gland function is depended on the appropriate amount of iodine.

Fluoride and iodine are similarly structure, since both belong to the halogen group, but $\mathrm{F}$ is more active chemically than iodine thus it binds with iodine receptor and inhibit the activity of $\mathrm{Na} / \mathrm{K}$-ATPase and reduce iodine level in the thyroid gland (Zhan et al., 2006) leading to distributed enzyme activity that stimulate the conversion of thyroxin (T4) into triiodothyronine (T3) and interrupted the physiology of thyroid gland (Xiang et al., 2009). These findings confirm that ingestion of sodium fluoride can result in hypothyroidism these results are in accordance with 
Agalakova and Gusev, (2012) who mentioned that, high fluoridation water increase the incidences of hypothyroidism and causing increase in the number of atretic follicle. The major reproductive system problems include ovulation disorder and folicuogenesis disturbances which leading to infertility.

\section{CONCLUSION}

From the current work we concluded the following:

1- Sodium fluoride had adverse effects on the ovary.

2- Sodium fluoride toxicity reduces the number and diameters of ovarian follicle.

3- Sodium fluoride had adverse effects on the coefficient of the female reproductive system.

4- Sodium fluoride inhibits the fertility of female adult Albino rats.

\section{Declaration of Conflicting Interests}

The authors revealed that there was no potential conflicts of interest.

\section{REFERENCES}

ABDEL DAYEM M. A., HASSAN M. , FADEL M., AND SENOSY W.2020. Effect of A Non-Steroidal Aromatase Inhibitor on Ovarian Function and Synchronicity of Estrus in Ewes at Subtropics.Journal of Applied Veterinary Sciences, 5(4): 1 - 9. DOI:10.21608/JAVS.2020.117991

ABDELSAMAD, D RUOYU K.E., WILLIAM, H., AND KUTTEH, 2018. Thyroid Function and Reproduction, DOI: ,10.1016/B978-0-12-8012383.64521-X,In book: Reference Module in Biomedical Sciences

AGALAKOVA, NI, GUSEV, G.P., 2012. Molecular mechanisms of cytotoxicity and apoptosis induced by inorganic fluoride. ISRN Cell Biol:1-16.

AL TAEE, S., H. K, KH. AND ISMAIL H., 2020. Review on some heavy metals toxicity on Freshwater Fishes. Journal of Applied Veterinary Sciences. Egypts Presidential Specialized Council for Education and Scientific Research, Jul 2;(0):78-86. doi.org/10.21608/javs.2020.100157

AL-SABAAWY, HB, AND AL-KAISIE, B.I., 2020. Effects of Sub Lethal Concentrations of Sodium Fluoride on Sperm Activity and on the level of Sex Hormones of Adult Male Albino Rats. The Iraqi Journal of Veterinary Medicine, Baghdad University College of Veterinary Medicine; 28;44(2):928.doi.org/10.30539/ijvm.v44i2.980

BAKEER, M.R. SALEH, S. Y. GAZIA, N. ABDELRAHMAN, H. A. ELOLIMY, A. ABDELATTY A. M. 2021. Effect of dietary pumpkin (Cucurbitamoschata) seed oil supplementation on reproductive performance and serum antioxidant capacity in male and nulliparous female V-Line rabbits, Italian Journal of Animal Science, $\quad 20: 1, \quad 419-425, \quad$ DOI: 10.1080/1828051X.2021.1889406
BHATTACHARYA, P. AND SAMAL, A.C., 2018 Fluoride contamination in groundwater, soil and cultivated foodstuffs of India and its associated health risks: A review, April 2018.

CHOUBISA, S.L., 2012. Status of fluorosis in animals. Proc Natl Acad Sci India Sect B Biol Sci 82 (3):331-9.

CHOUBISA, SL., 2013. Fluoride toxicosis in immature herbivorous domestic animals living in low fluoride water endemic areas of Rajasthan, India: an observational survey. Fluoride;46 (1):19-24.

KRASSAS, G.E., POPPE, K. AND GLINOER, D., 2010. Thyroid function and human reproductive health. Endocrinol Rev; 31:702-55.

KANG JH, KUECK AS, STEVENS R, CURHAN G, DE VIVO I, ROSNER B, ET AL., 2013. A large cohort study of hypothyroidism and hyperthyroidism in relation to gynaecologic cancers. Obstet Gynecol Int; $721-43$.

KUMAR, A., 2015. .Effect of Fluoride Toxicity on the ultrastructural Morphology of the ovary of mice, Article in International Journal of Applied Research and Studies . August. DOI: 10.13141/RG.2.2.26997.17147,

SURVARN, K, LAYTON,C.H., BANCROFT, J. AND BANCROFTS, 2018. Theory and practice of histological techniques $.8^{\text {th }}$ ed. New York: Elsevier Press ;2018.1-30p.Doi:10.1016/b978-0-443-102790.50010-5.

ZHAN, X.A., LI, J.X., WANG, M., XU, Z.R., 2006. Effect of fluoride on growth and thyroid function in young pigs. Fluoride;39(2):95-100.

XIANG, Q., CHEN, L., LIANG, Y., WU, M., AND CHEN, B., 2009. Fluoride and thyroid function in children in two villages in China. J Toxicol Environ Health Sci;1:54-59

How to cite this article:

Hadeel, B. AL-Sabaawy ${ }^{1}$ and Bushra, I. ALKaisie' 2021. The Effects of Sub-lethal Concentrations of Sodium Fluoride on the Number and Diameters of Ovarian Follicles. Journal of Applied Veterinary Sciences, 6 (3): 20 - 24.

DOI: https://dx.doi.org/10.21608/javs.2021.74681.1077 